obstruction. He suggested that the mechanism of benefit might be on the disseminated intravascular coagulation which he believed to be an important cause of death after burns and smoke exposure.

Dr $\mathrm{R}$ Gleadle gave a presentation on current methods of pharmacological prophylaxis and treatment in nerve gas poisoning.

(Submitted by Lt Col G O Cowan, FRCP Ed, RAMC)

\title{
Entomology in the Armed Services
}

An Occasional Royal Entomological Society Seminar was held at the Royal Army Medical College on 25 March 1981. This meeting was a joint venture between the Ministry of Defence and the Royal Entomological Society and attracted an audience of about 100, composed of both servicemen and civilians. The meeting was divided into three sessions, each concerned with a different aspect, namely the viewpoints taken by the three Services, entomological research and conservation.

The meeting was opened by Maj Gen J P Crowdy, Commandant and Postgraduate Dean of the Royal Army Medical College. After welcoming the various groups represented, the three Services, professional pest controllers and Fellows of the Royal Entomological Society, he went on to give a brief history of the College, pointing out the famous entomologists who had been involved with the Services in the past, such as Ross, Leishman and Bruce.

The subject of Medical Entomology was introduced by Brig D E Worsley, Director of Army Preventive Medicine. He continued the historical theme by describing how entomology had developed from the hobby of collecting insects in the 18th and 19th centuries to the realisation that insects could be vectors in the spread of disease. Entomologists in the Services made many great advances here as they were able to work overseas in the problem areas. Nowadays entomologists play a dual role, researching into pest control on the one hand and conserving rare insect species on the other.

The first session chaired by Lt Col I P Crawford, Parkes Professor of Preventive Medicine, concentrated on the perspectives taken by each of the three Armed Services. Dr N R H Burgess, Ministry of Defence Adviser in Entomology, began the session by outlining the work of the Entomology Unit, Royal Army Medical College. The three members of staff are involved in several areas of entomology including teaching about insect-borne diseases and their control, and research into new methods of control. The unit also acts as an advisory service for both civilian organisations and the Services, and as an information and identification centre. This latter role is normally shared with the British Museum, the London School of Hygiene and other institutes, as in 1980 alone the College received some 1500 specimens for identification.

The Royal Navy viewpoint was aired by Surg Lt Cdr P D Clarke from the Royal Naval Hospital, Haslar. He explained that the Navy has very few problems with insect borne diseases, although there are still outbreaks of scabies due to 
crowded quarters on ships and close contact of sailors on exercises. Crab lice are another problem, especially after visits to foreign ports! Now and again specific diseases occur, such as tick typhus from Zimbabwe. However, there has been no record of malaria amongst sailors over the past three or four years due to efficient prophylaxis.

Whilst insect borne diseases are few, insect pests are still common on board ship, where the most abundant creature is the cockroach. These are carried onto ships with stores which are held centrally, and easily reinfest a 'clean' ship. Most modern ships have copious false panelling which encourages infestation, as indeed does the attitude of the sailors who regard the cockroach as a friendly companion. In addition to this, many stores are collected from abroad and often contain weevils and beetles which then spread to the central stores in Britain and hence to a large number of ships.

Flt Lt D Marshall of Royal Air Force Strike Command began his talk on entomology within the RAF by stating that low lying swampy areas make excellent airfields! In spite of this however, the RAF has little trouble from insects, except of course the cockroach. Flt Lt Marshall discussed the historical aspects of entomology in the RAF and explained that the decline in the number of Air Force bases abroad has led to a decrease in need for specialist knowledge. Servicemen are now taught at second hand in Britain, few working with Pest Control Units overseas, and usually civilian contractors are brought in to control infestations of cockroaches and other pests.

However, the RAF still has one long-term involvement with pest control that is the disinfestation of aircraft flying in from other countries. Service crews and ground staff are trained to spray the aircraft and to look out for such things as black widow spiders hidden in luggage.

The second session covering the research aspects of entomology was chaired by Dr Burgess, who discussed some recent projects carried out by the Entomology Unit of RAM College, pointing out that any research undertaken by the unit was always practically based and often in response to a particular problem.

For instance, in 1974 the Entmology Unit was asked to find a method of controlling horseflies on an MOD range in Wales where these flies were becoming a considerable nuisance. Spraying was considered impractical as the flies were breeding over a large area of pastureland, and at a density of one larva per square foot! As is so often the case, a chance observation provided the clue. It was noticed that horseflies landed on the dark blue pullover of one member of the team, in preference to any other coloured clothing, and so a series of experiments was conducted to find which colour attracted horseflies most. Coloured panels coated in a special non-drying adhesive were used, and eventually it was found that dark grey attracted significantly more flies than any other colour in varied environments, and yellow was especially unattractive. Dark grey sticky panels were placed over the range and in a period of only five weeks caught 30,000 female horseflies. The suggestion that the Army paint everything (and everybody) yellow was however rejected!

To bring things right up to date, Dr Burgess described a project which is still in progress. Once again the problem is to find an alternative to spraying, 
but this time on a salt lake in Cyprus. Not only is the terrain inaccessible but there are several thousand flamingoes which feed seasonally on the lake. The Entomology Unit is supervising field trials of a synthetic juvenile hormone (altosid) which is dropped from a helicopter over the lake, and will only affect mosquito larvae. After three months treatment the control seems to be working and families are now picnicking around the lake as there are so few mosquitoes.

Mr K N Chetwyn continued the report of the Entomology Unit's research by discussing their longest running project - the ten year investigation to show that cockroaches spread disease. Over this time it has been shown conclusively that cockroaches do pick up and carry a wide variety of bacteria, protozoa and viruses from the environment, which often happens to be a sewer or dustbin. They will readily feed on faeces, surgical swabs and human food and, due to their large size, are probably more efficient at spreading infections than flies. The evidence is there for bacterial transmission and even multiplication within the gut of the cockroach, but the hardest part of the project is to convince hotel and restaurant owners (and even housewives) of the problem. Most will deny the presence of cockroaches on the premises, and may never consider controlling them as it can be an expensive operation.

The subject of pest control led naturally to the next speaker Dr P R Chadwick of the Wellcome Research Laboratories. He made the analogy between insect control and running a war, and introduced PTE Schweik, a square bashing cartoon soldier who is to be left alone in the jungle for a night. He explained the actions this soldier would take to protect himself from insects, from isolation by mosquito nets and repellents, to the psychological satisfaction of 'shooting' insects with an aerosol.

Next came the case of an airborne detachment of 250 men, presumably including PTE Schweik, in the bush for a period of a month. Dr Chadwick described their aims of disease control, nuisance control and their actions (vegetation clearance, ULV spraying, nets to keep flies in latrines and out of kitchens, and prophylactic drugs). Finally Dr Chadwick described the problems that would be encountered by a permanent establishment with married quarters and other facilities in a tropical country. The aim is now long-term protection from insects and involves construction of adequate drainage, the design of insect-proof buildings and fittings, and education of families and soldiers in matters of hygiene and pest control.

The morning sessions were brought to a close by Dr R P Lane of the British Museum $(\mathrm{NH})$, who with the aid of some particularly gory transparencies, described his research into leishmaniasis. He has been working closely with the Army in Belize in an attempt to determine why the incidence of leishmaniasis amongst soldiers rose by 20 fold during the period 1979-81, and has remained unusually high since. He described the disease, which may affect cartilage or the internal organs, or as in Belize, causes open lesions on the skin, and also gave details about the Phlebotomus sandfly vector. The animal reservoir has always been thought to be rodents, although lately many other species, especially sloths, have been implicated, and it seems that the soldiers began to mimick these 
(the rodents not the sloths) by 'digging in' and spending the night in scraped out hollows. To a sandfly, these were just large rodents in their burrows and hence potential sources of blood, so the number of cases of leishmaniasis increased. This work is still continuing, but the seminar provided an insight into an interesting piece of liaison between a military and a civilian organisation.

The afternoon session, entitled 'In defence of the insect' was introduced by Dr Burgess who gave an illuminating talk on the insect in Art. In 15 minutes he covered the vast plethora of insects in every type of art, from paintings to pottery (even chamber pots) and from pub signs to plays. Insects were depicted in jewellery by the ancient Egyptians, in carvings by the Aztecs (in particular a 15 in stone carving of a flea) and throughout the ages by painters.

Nowadays this form of art is often replaced by photography, and $\mathrm{Mr}$ A S Allen from the Department of Medical Illustration at the Royal Army Medical College described his often perilous task of working with entomologists. After detailing the cameras, lenses and other accessories needed for close-up work, he outlined his lightweight field kit comprising a camera, a $50 \mathrm{~mm}$ standard lens or $105 \mathrm{~mm}$ long focus lens and several close-up lenses. In the laboratory he used extension tubes or bellows for homing in on insects, sometimes in conjunction with a coaxial ring flash.

Then came the Conservation proper. Lt Col C N Clayden who is the MOD Conservation Officer based in Defence Lands 3, gave a summary of the MOD land in the United Kingdom. This covers a total area of 618,040 acres and includes chalk downlands, woods, breckland, meres, heath and 212 miles of coastline. Part of Col Clayden's brief is to establish records of both plant and animal life and also archaeological sites and ancient buildings on all MOD lands, a task he sets about with boundless energy and the help of about 4,000 volunteers. $\mathrm{He}$ is also preparing sensitivity maps and management plans for the areas in order to conserve habitats and rare species. One site contains a third of all the spider species found in Britain, others are havens of otters, natterjack toads and Dartford warblers. One 2,000 acre site has as many as 328 species of moth, 34 species of butterfly, and 24 species of dragonfly and damselfly; so the list goes on. Managing the areas is not easy, but many areas now have volunteer conservation groups to look after them. The erosion of sandy ground, or of heathland by silver birch are constant problems which need to be solved by long-term management policies, if we are to save many of the rare species in Britain.

Mr. A. E. Stubbs of the Nature Conservancy Council echoed the need for careful management and expressed the view that MOD land was now, due to large acreage of each range, of possibly greater importance in wildlife conservation than the smaller nature reserves and SSSI's. These sites are generally 'islands' surrounded by cultivated farm land which is regularly sprayed with pesticides and herbicides, and hence are still vulnerable to destruction. He went on to pinpoint those areas in particular danger, such as meadows and heathland and stressed the importance of such sites as roadside verges and glades, dead timber in woods and water filled bomb craters as essential microhabitats. Much of today's farm management tends to remove these 'waste' areas for the sake 
of efficiency, and wildlife is suffering as a result. Finally, he explained the necessity of leaving havens for wildlife during conservation management, as certain forms of management provided by botanists for example may be destructive to insects.

After a period of discussion between members of the audience and a panel of lecturers, Dr R C Rainey, OBE, FRS, President of the Royal Entomological Society gave the closing address to a most enjoyable day.

(Submitted by Mr A M Walker and Dr N R H Burgess)

\section{ACADEMIC ACHIEVEMENTS}

FRCS(Edin)

FRCR

MRCP

MRCGP
Capt T W Davies, MB, BCh, RAMC.

Maj D A D'Alton, MB, BCh, MRCGP, DObstRCOG, RAMC.

Capt J G Malone-Lee, MB, BS, MRCP, MRCS, RAMC.

Capt J P H Fine, MB, BS, MRCS, LRCP, RAMC. Maj P J Hartrey, MB, BCh, RAMC. Capt (Mrs) A M Hodgson, MA, MB, BChir, RAMC. Maj S A St J Miller, MB, BCh, RAMC. Capt J D R Morrison, MB, ChB, DRCOG, RAMC. Capt (Mrs) P Parish, MB, ChB, DRCOG, RAMC. Càpt J Spincer, MB, ChB, PhD, BSc, RAMC.

\section{Additional Qualifications}

Lt Col K Edgington, MRCS, LRCP, DAvMed (Eng) AFOM, RAMC, has been promoted from Associate to Member of the Faculty of Occupational Medicine.

Maj J A East, MB, BCh, RAMC, has been elected to the Associateship of the Faculty of Occupational Medicine. 